\title{
WindHAger ÁkOs*
}

\section{TERÉNYI EDE MISEPARAFRÁZISA NÉGY OLVASATBAN. A FIÚ(ISTEN) DRÁMÁJA}

Kulcsszavak: Terényi Ede, missa brevis, megszakitott hagyomány, szakrális tartalom

\author{
„Amikor verset ír az ember \\ nem írni volna jó.” \\ (József Attila, töredék)
}

\section{TERÉNYI EDE FARKAS UTCAI MISÉJE}

A Kolozsvári zeneszerzők - zeneszerzők Kolozsváron című tudományos konferencia ${ }^{1}$ kulcskérdése ihlette azt a szellemtörténeti kutatást, amely Terényi Ede és a Város (értsd: Kolozsvár) kapcsolatát vizsgálta. Az a cél lebegett előttem, hogy a zeneszerző, valamint a szellemi és társadalmi közeg kapcsolatát megrajzoljam. Követve Németh László, Márai Sándor és Cs. Szabó László esszéíró hagyományát, megfordítva közelítettem a tárgyhoz: a Farkas utcai templomba megálmodott Miseparafrázis elemzése révén mutatom meg a szerző kolozsvári attitűdjét. Vállalásom a zenei alapszöveghez készült többrétegú glosszát eredményezett, amely a hagyományt egyre mélyebben beengedte az értelmezés folyamatába. A Miseparafrázisok a XVII. századi Erdélyból címú vonószenekari darab négy olvasata együtt adja ki azt a képet, amelyben Terényi a szeretett Városa polgára, ahogy az erdélyi szakrális örökséget megtartva aktualizálja, ahogy kolozsvári zenei együttesekben fogalmaz, végül ahogy a Farkas utcai templom spirituális otthont nyújt számára. Jelen esszé tehát életrajzi, műelemző, hermeneutikai és teológiai olvasatból áll, és ezek egymásra rétegződésében rajzolódik ki választott tárgyam: az egyén és a Város symphoniâja.

* Windhager Ákos (1975), PhD, irodalom- és zenetörténész, szakíró, a budapesti Magyar Múvészeti Akadémia Múvészetelméleti és Módszertani Kutatóintézetének munkatársa, továbbá az Országút címủ kétheti lap rovatvezetőjj. E-mail: windhager.akos@mma-mmki.hu.

1 Kolozsvári zeneszerzők - zeneszerzők Kolozsváron. Nemzetközi tudományos konferencia. 2019. április 12-13. Szervező: Erdélyi Múzeum-Egyesület I. szakosztály, Erdélyi Zenetudományi Munkaközösség. 


\section{TERÉNYI EDE ÉS KOLOZSVÁR - ÉLETRAJZI ELŐOLVASAT}

Terényi Ede 1952-ben érkezett meg Kolozsvárra, a városba, amelyet azóta otthonának tekint. A genius locit keresve se találhatott volna nála hűségesebb alanyt; itt telepedett le, itt házasodott meg, itt tanított, itt jegyezte le fentről súgott alkotásait, és itt hozott létre közösséget. Terényi Ede számára Kolozsvár az újraszülő város, mégha ez pimasz búcsúintést is jelent Marosvásárhelynek. A két város a szerző tekintetében tükörképe egymásnak: víz köré települ, hegyre mászik, és az Urbs caelestis felé tör, azaz egyetemes (sic!) város. Kolozsvár bevétele Terényi számára tehát nem Vásárhely feladása volt, még kevésbé annak megtagadása, hanem kiteljesítése. A nyüzsgő nagyvárosba költözéssel magával hozta a szülővárosát, beleoltotta azt nagy Erdélyországba, a magyar összkultúrába és a teljes európai műveltségbe. Akár Ligeti, aki Dicsőszentmártonból az egyetemes véghatárokig tolta ki zenei horizontját, azonképp földije is a világi és égi végtelenbe ért el a Szamos partjáról.

Tiszteletlenség lenne a szemérmes alkotó életének részleteit közszemlére tenni, noha annyit azért fontos megjegyezni, hogy Kolozsvárott kapta élete legjelentősebb beavatását. A vásárhelyi években Trózner József hatására a fiatal múvészjelölt már kereste a helyét, de azt csak Kolozsvárott találta meg. Tanára útmutatását követve felvették a Zeneakadémia zeneszerzés szakára, aminek következtében felhagyott orvosi terveivel, lemondott zongorista pályájáról és a zene általi gyógyításnak szánta az életét: zeneszerzővé lett. Trózner felnyitotta már tanítványa szemét sok romantikus szerzőre (például Anton Brucknerre, Franz Schmidtre és Antonin Dvořákra), és megannyi boldog órát töltöttek Mozart- és Schubert-olvasással; de mindez a kolozsvári Kodály-, Debussy- és mindenekelőtt Bartók-stúdiumokban teljesedett ki. Vásárhelyen Trózner József felesége, Erkel Sarolta révén beavatódott a romantikus magyar zenébe, Kolozsvárott megismerte Jodál Gábor révén a kortárs magyar zenét: Kodályt. Az eszménnyé magasodott Bartók pedig mindkét városban rátalált, ám az érettebb egyetemista tudta őt mélyebben megérteni.

Kolozsvár tehát zeneszerzővé tette, tanárrá avatta, és megtartotta őt. Hívta őt Budapest, de Bukarest is, várt rá Darmstadt és a nagyvilág, amelyet időről időre fel is keresett, de Kolozsvárt a fél világért nem adta volna. Múveiben viszont bebarangolta az egész földkerekséget, Finnországtól Japánig, Amerikától Indiáig, Tahititől a Kraszna völgyéig. Valós világjárás, képzelt túrák és belső utazások során született meg a színes-szimfonikus panoptikum. A jellegzetes Terényi-geográfia annyiban tér el a Baedeckertôl, hogy amíg utóbbi mindenben meglátja a német Bürgertumot, addig a zenei világrajz minden elemében kicsit felsejlik a Farkas utca, Házsongárd vagy Fadrusz Mátyás király portréja. Lényeggé szűrve a külső elemeket, a világot képezte le, de nemcsak emlékmûveiben, hanem barátságaiban is. Az utolsó pillanatig kitartott Vermesy Péter és Szabó Csaba mellett, s mai napig őrzi Balassa Sándor barátságát. A végleteket egyesíti magában társasági középpontként, tanárként és alkotóként, s eh- 
hez éppen a végletek városa tud teret és spirituális helyet nyújtani. Nem mellesleg, éppen Kolozsvár segítette abban is, hogy felnőttként is háborítatlanul megőrizze magyar identitását. Amíg dalokat és kórusmúveket magyar és latin nyelven írt, addig a zeneakadémiai óráit rendszerint románul kellett tartania. Múveivel azt nyilatkoztatta ki, hogy Constantin Brâncuși, George Enescu és Kájoni János az egyetemes erdélyi kultúra része, hasonlóan Bakfark Bálinthoz, Bornemisza Péterhez vagy Tinódi Sebestyénhez. A kincses városban ismerik, nevére az emberek felkapják a fejüket, s ha nem jelenik meg hosszabb ideig, aggódva keresik ifjak és idősebbek. Így, amíg a zenében övé az egész világ, addig ő már végérvényesen Kolozsváré.

\section{MISEPARAFRÁZIS A XVII. SZÁZADI ERDÉLYBŐL}

1992-ben született meg az - általa alkotott mûvész pályakép kulcsfogalmát használva - alkotói fennsíkon a Miseparafrázis a XVII. századi Erdélyból címú vonószenekari kompozíció. A mú rímel az 1980-ban befejezett Variaţiuni pentru orgă pe o temă din sec. al XVII-lea címú orgonakompozícióra, illetve megidézi a tizenkét historikus concertót is, de azoktól mégis független. Az öt misetételt tartalmazó alkotás mindegyik tételét egy-egy Kájoni- vagy vele kortárs szerző témája nyitja, amelyek azonban önálló életre kelnek. Coca Gabriela hívja fel a figyelmet arra, hogy ebben a tökéletesre csiszolt darabban az életmú esszenciális ötvözése történik meg, tulajdonképpen a scordaturák, a harmóniafúzió és a dallam „függőlegesítése” is együttesen hozza létre az œuvre új minőségét. ${ }^{2}$ Maga a szerző még annyit füzött hozzá a darabjához, hogy a Farkas utcai református templom terét képzelte el műve írása közben. Így válik számára a konkrét építészeti tér a Makovecz-concerto ( $A$ héttornyú vár - versenymú szólóhegedûre, vonósokra és ütőhangszerekre, 1993) után ismét fontossá, amit tudatosan és tudattalanul is beépít a zenei térszerkezetbe. Így elmondhatjuk, hogy a $\mathrm{Mi}$ separafrázis esszenciális kolozsvári zene.

\section{A mise - szoros olvasat}

A Miseparafrázis a szoros olvasatot három pontban provokálja: a múfaj meghatározásában, az előadói együttes precíz behatárolásában, végül a szerkezeti súlypont megtalálásában. Ehhez képest a párhuzamos harmóniasíkok akkordmultiverzuma könnyú kérdésnek tűnik. A Miseparafrázis címéből következően miseként értelmezhető. Ezt támasztja alá az is, hogy a klasszikus besorolás szerint paródiamiséről beszélhetünk az említett és a partitúrában gondosan feltüntetett tudatos idézetek miatt. ${ }^{3}$ Szintén a

2 Coca Gabriela: Terényi Ede. Parlando 2016/5, 12.

3 Terényi Ede: Mass-Paraphrases for Strings, In: Ede Terényi: Chamber Symphonies, [szerzői magánkiadás], Grafycolor, Cluj, 2007, 1-47. 
misejelleget erősíti az öt tétel missa ordinariumot idéző elnevezése, valamint a missa brevis kimutatható szerkesztési hagyománya. Később azt látjuk majd, hogy egyik besorolási kísérlet sem igazolható teljesen. Így a klasszikus öt misetétel: Kyrie, Gloria, Credo, Sanctus és Agnus Dei rögtön kérdés elé állítja a szoros olvasatot. A hagyományos (zeneileg szerkesztett) misében a Sanctust a Benedictus kellene, hogy kövesse (vagy legalábbis összevont címként kellene megjelennie), míg a missa brevisekben a Credo kimarad. A Miseparafrázis hangszerelése ismét csak több módon értelmezhető. A partitúra szerint az előadói együttes nagy vonószenekar, amely változatos módon szólal meg. A Kyriêben és a Gloriäban tizenkét hegedû-, négy mélyhegedû-, két cselló- és egy nagybőgőszólam jelenik meg, ám a Credobban és Sanctusban egy vonósnégyes és egy vonóskar concertál egymással. Az Agnus Dei helyzeténél fogva nemcsak a témákat és a programot összegzi, de a korábbi hangszerelést is, így a soli vonósnégyes mellett az első tételek osztott vonósegyüttese muzsikál. Tovább fokozza a hangszín sokszínűségét, hogy sok esetben az első hegedű önálló, szólista szerepet kap (például a Sanctus esetében), illetve a hangzás következtében több ízben orgonát (Agnus Dei) és ütőapparátust (üstdobot, harangot) vélünk hallani. ${ }^{4} \mathrm{~A}$ harmadik jellegzetesség, amely a szoros olvasatot provokálja, az az egyes tételek terjedelme. Noha nincs kőbe vésve, hogy a Credo legyen a mise súlypontja, azt szakrális súlya (hiszen a teljes üdvtörténetet tartalmazza: a mi Urunk, Jézus Krisztus születését, kínszenvedését és feltámadását) mégis kiemeli a többi tétel közül. Az egyes zeneszerzők a rejtett programnak megfelelően súlyozzák a tételeket, így Kodály a Missa brevisben az utolsó tételt nyújtotta a leghosszabbra, és annak tartalmát emelte ki érzelmi többlettel. Terényi viszont a Kyriével tett így, amely önmagában olyan hosszú, mint az azt követő három tétel. Így az első és az utolsó tétel, amelyek tematikailag is összeillenek, együtt alkotják az Istennel való találkozás időtartamának a felét. Ennek jelképiségét majd később fejtem fel, viszont e külsődleges paraméter ismételten figyelmezteti az olvasót, hogy nem foghat hozzá klasszikus miseolvasási módozattal a Miseparafrázishoz.

A harmóniai olvasatot pedig végképp megfricskázza a következetes, szinte már rigorózus és makacs A-centrum. Bármelyik tétel kezdetét, kidolgozási szakaszát, visszatérését nézzük is, az A-centrumnak nincs elsődleges szerepe, a zárlatokban azonban átható erővel szabadul (f)el. Mintha mindaz, ami addig a harmóniák terén történt volna, csak földi poroszkálás lenne az égi A-sugárúthoz. Az A-centrum jelképisége az életmúvön belül és attól függetlenül éppen úgy provokáció tehát a harmóniai olvasat útjában, mint a hol durván, hol finoman exponált kisterc-ostinato. Egy barokk múben, főképp egy manierista madrigálban a fényességtől kistercre levő

4 Így nyilatkozott Molnár Tündének maga az alkotó. Ld. Tünde Molnár: Muzica pentru orgă în secolul al XX-lea în România. Compoziții noi, analize stilistice şi interpretative (The Music for the Organ in the Twentieth Century in Romania. New Composition, New Analysis and Interpretations), Grafycolor, Cluj, 2005, 208. 
A-centrum jelképiségét könnyedén fordítanánk, a Miseparafrázis sokszorosan telített, többszörösen felülírt szimbólumterében mindez azonban elsősorban kérdésfeltevésként hangzik fel.

\section{Kyrie}

A Kyrie hagyományosan ABA-szerkezettel bír, azaz a két Kyrie eleison egymást ismétlő szakasz, amelyekkel a Christe eleison áll szemben. A Miseparafrázis esetén a 93 ütemnyi kezdőtételből az első 60 ütemben a kyrie-intonáció szólal meg kimért lassúsággal. Az Uram irgalmazz! latin megfelelője, a kyrie szó lüktetése negyed és nyolcadpár ritmusképletére bontható le. Brevisre és félhangokra augmentált ritmusváltozatban hangzik el a tételben számtalanszor, osztinált basszusritmusként. A 6/2es ütemek a makacs ritmusképlet következtében párosával alkotnak egységet, s így éppen háromszor ismétlődik meg a „Kyrie”-ritmus az „eleison” [ee-lei-son: három negyedhang] egyenletes lüktetését is felidézve. A ritmusképletet előbb a nagybőgők játsszák, majd a csellók, később a mélyhegedúk csatlakoznak. Az ötödik ütemben a G-alapcentrum következtében lokriszi pozícióban lép be a paródiadallam, amely Kájoni egyik Organo Missale-témája. Az idézett, szomorú siratódallam kiemeli a Kyrie megrendültségét. A témát minden hangregisztert bejáró fugato növeszti hatalmas tablóvá a 40. ütemig. A dinamikai és harmóniai váltások következtében a fájdalmas dallam megdicsőül olyannyira, hogy a 30. ütemtől kezdve a basszus-ostinato is megszűnik, és minden hangszer, ha elhangoltan is, de a témát szólaltatja meg. A 40-43. ütemek epizódja az első Kyrie-szakasz legdrámaibb pillanata, amikor az üvöltéssé torzuló könyörgés zokogásba fordul, és fojtott hangon Gesz-alapú, kilencelemú hangfürtben szólal meg. A tompa álzárlatból brácsa A-hang vezet ki, és a téma egyszerúbb harmóniákban ismétlődik meg. Az Uram, irgalmazz! szakasz végül az előző harmóniai tömb ellenpólusán, egy tiszta $\mathrm{C}$-hangtoronyban nyugszik meg.

A Christe eleison szakasz eltérő zenei mikrokozmoszt teremt. A Christe eleisontéma ötütemes félperiódusokban nyilatkozik meg, amelynek kérdésrésze repetitív mikromozgás, a válasza pedig perpetuum mobile-ingajárás. A továbbra is 6/2-es ütemekben az első két brevis erejéig csak ismétlődő hangokat hallunk, mert a mozgás az utolsó harmadban kezdődik el. A ritmusképlet hatására a zene most (is) hármas lüktetésben mozog - és ennek szakrális jelképe megegyezik a kyrie-szakasz hármas ritmusáéval (ti. a háromszemélyú Egyisten hangszimbolikája). A nyugodtabb harmóniák mentén a tonális centrum eltolódott az $\mathrm{F}$ felé. A téma előbb a középszólamokban mutatkozik be, majd egy epizód erejéig a magas(ság)ban is felhangzik, ám ezután tovább már nem fejlődik. A végső kifejlődés pusztán rituális megtisztulás volt a beavatás megkezdéséhez, mert miközben a téma visszatér oda, ahonnan vétetett, a magasban kétszer intonál a lefelé lépő kisterc drámája. Jól hallhatóan ez adja a tétel igazi kulcsát, mert erre reagál a leghevesebben, minden korábbi témát, ritmust és harmóniát elsöprő vonósgörgeteg. A harmadik azonos szerkezetû́ epizódban újabb 
kísérlet történik a kisterc „kinyilatkoztatására”, de ott már a hangköz tritónusszá torzul. Ezzel a bünbe esett bőnegyeddel lépünk vissza mindössze négy ütem erejéig a kezdő kyrie-témáig. A hirtelennek tűnő lezárás váratlanul a-mollban történik. A zárlat szembemegy a narratív logikával, mert semmiből nem következik, semmi előre nem jelezte. A teljes mú ismeretében az állapítható meg, hogy az „A-centrum” a mise „programja”, amely ebben a tételben úgy értelmezheto, mint a Kyrie Gesz-clusterére és $\mathrm{C}$-hangtornyára adható egyetlen szakrális válasz.

Ha a tételt még egyszer meghallgatjuk, akkor számos, kortárs zenei párhuzamot találunk. Így, az a pillanat, amikor a vonósbasszus felett alig hallhatóan szólal meg a fájdalmas dallam, Gija Kancseli vonósdrámáit idézi fel. A komponálás idején Romániában Kancseli művei nem voltak elérhetőek sem partitúrában, sem koronglemezen, előadáson még kevésbé, így a párhuzam alapvetően korszakkijelölésben segít. Mindkét szerző azt a gesztust ábrázolja, ahogy a misztikus anyagot (legyen az „népi” vagy „régi”) a környezete nyers és vad indulattal fogadja be, amiképpen az „avítt” szakrális és az elevenen lüktető anyag reszketve feszül egymásnak. A kíséret és a téma egymásnak feszülése azért is hátborzongató, mert, ahogy korábban bemutattam, a basszus ostinato a több ezer éves Kyrie szócskából képzett szózene, amely e hörgés révén válik nagyon maivá. Szintén a befogadói horizont érzékeli rokonnak a téma-clusterré növő polifon szólam vezetését Ligeti mikropolifon stílusával. Az egybeesés ezúttal is a korszak sajátja, a párhuzamos zenei folyamatok szabadon engedése és predesztinált egybefüzése logikus következménye a Bartók utáni zenei folyamatoknak. Végül Steve Reich minimalizmusát is párhuzamba hívja az öttételes félperiódusban gondolkodó Christe elesion. A nyolc azonos hang után bekövetkező tonális jellegú mozgás olyanynyira új dimenziót képez a tételben, hogy legalább fél percbe kerül, mire a fülünk megszokja a monotóniáját. Reicht ismerhette ugyan Terényi, de a Miseparafrázis komponálása közben már egy évtizede meghaladta a minimalizmust. Végül, a fájdalmas Kyrie esetén nem felejtkezhetünk el a szerző egyik kedvenc Mesteréről, Mozartról se, mert a tétel kulcspillanata, a kisterc kétszeres kiemelése úgy lép ki a zenei környezetéből, ahogy a „Dreimalige Akkorde” a Varázsfuvola nyitányában.

\section{Gloria}

A Gloria (Allegro molto) tétel megértéséhez érdemes felidéznünk, hogy a „Dicsőség Mennyben az Istennek, békesség Földön az embernek!" szózat akkor hangzik el, amikor a pásztorok a kisdedhez sietve egy pillanatra bepillanthatnak a mennybe, ahol nagy a sürgölődés. Ezt a sürgés-forgást véljük hallani a tétel első húsz ütemében. A 4/4-es lüktetésű E-dúr szakaszban apró témasejtek (pl. E-Disz-Cisz) ismétlődnek állandó basszusképlet felett, amely nem meglepő módon E-Cisz-ellenpontba torkollik. A kisterclépések ismételt exponált helyzetủ alkalmazása kiemeli, megerősíti és kanonizálja a hangköz-ostinato programját a teljes kompozícióban. Utána azonban, azonos hangnemi keretben az égi dicsőséget idéző barokkos zenei formula harsan fel. 
A V alakú „trombitamotívum” Marc Antoine Charpentier és Jean-Baptiste Lully Te Deum-kiáltásaira emlékeztetve örvendezik, igaz, a basszusban négyelemú, kromatikus passacaglia-lépegetés társul hozzá. Végül a 41. ütemben immáron az áhított „földi békesség” ígérete hangzik fel Somlyai Miklós Magyar litánia dallamában. A 16. században az egész Kárpát-medencében elterjedt egykori dallamot többek között protestáns zsoltárban is megtaláljuk. A jellegzetes dór dallamban a földi békesség felmagasztosul, de azt, hogy mindez csupán a szerző mély vágya, jelzi a hátralevő száz ütem dramaturgiája.

A meghitt Békesség-idézet a kidolgozási részben újra és újra felbukkan ugyan, de a bevezető rész apró témasejtje válik a tétel központi zenei elemévé. Számos lefelé és felfelé futó fordítása a dicsőségkiáltást feszültté, zilálttá és kétségessé teszi. Mint ahogy Babits háborús zsoltáraiban az Istenhez szóló fohászok átkokkal keverednek, úgy rémlik fel a személyes és egyetemes dráma is a jelen dicsőségmondásokban. Hiába helyezi Terényi még háromszor a rettenetes vonósfutamok elejébe a késő reneszánsz litániadallamot, a zene nem nyugszik meg, hanem magával sodorja az idézetet is. Noha a kezdet sürgölődése jót ígért, az egykori pásztorok számára megnyílt Ég örömét előlegezte, a finálé mégsem igazolja azt. Inkább Illés vad dühével találkozunk, akinek ugyan olykor megnyílt a menny, és látta annak igazát, csak halálakor érthette meg annak békéjét. Így, a vad hajszában elcsigázott agg próféta utolsó leheletként kiszakadó sóhajára emlékeztet a záróütem sforzato E-hangtornya.

Dicsőíti a zene Istent? Mindenképpen. Solymosi dallama egykor és ma is az Ő dicsőségét zengi. A háttérben azonban ott húzódik a már a Kyriẻben megjelenített dráma, amely hihetetlenül szenvedélyes könyörgésre sarkallja a szerzőt. Az égi dicsőséget harsogó barokkos $V$-frázis csak a narratív keretet érzékeltette, de a zenei cselekmény a dallamsejt és a litánia összeütközésében bontakozott ki. A harmóniai szerkezet ezúttal is felborítja az értelmezést: C- és F-centrumok uralták a pástot, végül azonban minden visszatért a kezdő E-centrumba. Jellemző, hogy mind a dallamsejt, mind a litániatéma első ízben E-dúrban szólal meg, s csak utána következik moduláció.

\section{Credo}

Az egyházi zeneirodalom egyik legkülönösebb Credôja (Moderato) a Miseparafrázis középső tétele. Hiányzik belőle a hagyományos krédók fensége, békéje és hitvalló ereje, mert rövid, hajszolt és kétségekkel telt. A Kyriẻből eredő dráma folytatódik a Gloriából származó futammal, igaz, a Credóban az A-D-G-kvartfüzér ismétlődik, ahol a dallamsíkon a $G$ hang ismétel. Az egyszerre hármas funkciót betöltő kvartfüzér keretbe foglalja a Credót, mert előrevetíti a finálét: ugyanezt a formulát találjuk majd ott is. A füzér a Szentháromság tanát előlegezi meg, ahogy a hármasság a Kyriẻben harmonikus egymásutániságban, itt feszült egyidejűségben jelent meg. Az előző tételt is eluraló feszültséget átveszi tehát, de más módon küzd meg vele, más választ ad rá, illetve máshova transzponálja. Ezek együtt eredményezik, hogy a ha- 
gyományosan nyolcszakaszos misetétel összesen három szakaszból áll: a „Hiszek egy Istenben” és a „és hiszek Jézus Krisztusban”, valamint „és a Szentlélekben” kezdetű hitvalló mondatokból.

Az Organo Missaléból ezúttal ismeretlen szerző litániadallama szólal meg, amely hogy-hogy nem, ismételten a kisterc-nagyterc feszültségét használja ki. Ráadásul, a téma erősen emlékeztet a Bartók-operából Judit: „Szépen-halkan fogom nyitni” dallamára. A hathangú moll-téma az egész tételt áthatja, noha két epizodikus, de a környezettől idegen témával kerül majd összeütközésbe. A finoman vezetett szólamok először korálharmonizálást ígérnek, de lassú vonalvezetéssel kibontakozik a széles szimfonikus tabló. A szóló vonósnégyes és a tutti együttes összeütközését négyütemnyi H-gongütés zárja le. Az 51. ütemben kezdődik a Fiúistenről szóló hitvallás, ahogy ez a partitúra bejegyzésében is olvasható: „et incarnatus est.” Az előzőekben is már idézett, két tercet variáló ereszkedő téma szelíd kamarahangzásban csendül fel, amit halk E-, majd A-orgonapont kísér. A kromatikába csúszó utolsó frázist durva hangtörés állítja meg, amely után C-harangozás állítja helyre a tonális rendet. Az utolsó szakaszban éteri magasságba emelkedik fel a téma augmentált változata, miközben az alsó szólamok a korábbinál szabályosabb, népies táncritmusokban intonálnak dallamtöredékeket. A Fiúistenhez kapcsolódó rész szelídsége helyett szilajság jelenik meg, amely a már jelzett módon: az A-D-G-füzér hangszimbólumot hordozó rohanásába torkollik.

Az első szakasz D-centrumára a középső terület A-centruma, majd a zárószakasz E-centruma felel. Az első és az utolsó szakasz között jelentős tartalmi-programi egyezés figyelhető meg, így csupán az azonos témát, de más karakterrel és hangnemben megragadó középrész tér el. A monumentális első szakaszt az intim hangulatú második követi, ám a lezárás nem egyértelműen fenséges, hanem sokkal inkább széttöredezett, értékvesztett, tragikus. A befogadói horizonton az első szakasz késő reneszánsz, polifon motettára emlékeztet, a második szakasz háromszólamú barokk fugatóra, az utolsó szakasz viszont Leoš Janáček vonósdarabjaira. A három szakasz úgy viszonyul egymáshoz, mint a tételek Liszt Faust-szimfóniájában (ti. I.: Faust, II.: Margit, III.: Mefisztó), ahol az első két tétel eltérő jellegú építkezésére a harmadik dekonstrukciója felel. A Miseparafrázis esetében is az utolsó szakasz dekonstruál harsányságával, keserűségével és váratlan lezárásával.

\section{Sanctus és Agnus Dei}

Az Allegro tempójú Sanctus passacaglia-szakaszokra épül, amelynek témája - bár nincs jelölve - a kora barokk világát idézi. A bevezető négy és a záró hat ütem A-lokriszi témát hordoz, amelynek nincsen elsődleges köze a tétel belső programjához. Miközben a drámaiságot hangsúlyozzák, és ismétlő jelleggel az ünnepi üstdobütéseket és trombitaszót pótolják, harsányan intonálják a mise kisterc ostinatóját (A-b-Desz). A téma feltételezhetően a hozsannakiáltást imitálja. A programot te- 
kintve a tétel csak ezután kezdődik el: a passacaglia-téma idővel dübörgéssé, majd hörgéssé torzul, később átadja helyét félelmetes skálameneteknek. A hagyományos Sanctusok fényességét a basszus szólam imitálja, a magas szólamok azonban mégsem a „Mindenség Ura, Istene” szentségét zengik. A 13. ütemtől a záró 64. ütemig ugyanis a szólóhegedû eltéveszthetetlenül elkülönül a többi zenei anyagtól. Szólamában olyan Kájoni-dallam bontakozik ki, amely tétován lépeget, variálódik és ereszkedik, ám mindvégig bensőséges karaktert hordoz. A szentség megvallásánál tehát kettészakadt a zenei szövet, a lélek hangja hegedú érzékenyen felsír, a fundamentumok mélysége azonban ellenpontozza. „Tempora mutantur, nosque mutamur in illis”üzenheti a kettős zenei szövet. Az, hogy a világon túl, a végtelen teljességben rend van, jelzi, hogy végre egyértelmúen A-dúrban zárul a tétel. Ezúttal az A-centrum logikusan és előkészítve jelenik meg. Az Adagio-tempójú Agnus Dei a mise legrövidebb tétele, alig két percig tart. A legrétegzettebb zenekari apparátust alkalmazza ugyanakkor a szerzô, hogy a teljességhangzat hatalmas D-clusterét felépíthesse. Amíg a tétel kezdetén Kájoni Dies irae-idézete hangzik fel d-mollban, addig a tétel közepére a téma töredékeire esik. Ismét középpontba kerül a kisterc-osztinátó a magas szólamok dallamképzésében (a Dona nobis pacem! könyörgésénél), amely üvöltésig erősödik, és hatalmas hangfüzértömbbé szilárdul. A tizennyolc szólamú zenekar d-moll alapú clustert szólaltat meg, amely az utolsó ütemben diatonikus A-dúrra vált.

Szerkezetét tekintve a Kyrie a legösszetettebb, ám annak modellje figyelhető meg az Agnus Deiben is, mind a hangnem, az idézet, mind a szerkezet terén. A kerettételek úgy épülnek fel, hogy a kezdő dallamsejtből polifon szövet nő, amely hangfüzérré fejlődik tovább, végül A-zárlatba érkezik meg. A két tétel tehát organikusan épül fel egy dallamsejtből, miközben a szerkezeti terv mögött követhető szakrális-személyes program is áll. Velük szemben a három közbülső tétel a kezdésnél és a lezárásnál olyan önálló anyagot kapott, amely sem a tételen belül, sem a teljes múben később nem kerül elő. A keretmotívumok idézőjelnek tünnek a három tétel Kájoni-idézeteihez, ám több szempont arra enged következtetni, hogy szerepük több ennél. Bertolt Brecht vezette be a Verfremdungseffektet (röviden: V-effekt), azaz az elidegenítő effektusokat. Értelmezésemben mind a három tétel elején beavatkozik a szerző, hogy a kerettételekből áradó szakralitást valamiképp elidegenítse. Az, hogy a keretmotívumok felruházhatók liturgikus olvasattal, csupán kiemeli a jelentőségüket, ahogy az is, hogy a Gloria esetén a V-effekt témasejtváltozatai a dicsőségkiáltásba is beleavatkoznak. Az értelmezés végső nagy kérdése, hogy az „Isten báránya”-zárótétel viszont miért nincs elidegenítve, miért fejlődhet organikusan és emelkedhet fel a megbékélést hozó éteri A-dúrig. 


\section{A MISE SZEREPE AZ ÉLETMÚBEN - HERMENEUTIKAI OLVASAT}

A Miseparafrázis szoros olvasata alapján kiderült, hogy a mú spirituális tartalommal bír, és az életmú olyan központi darabjaihoz kötődik, mint az Isteni színjáték (1971), a Mephistofaust (1999) vagy a kései $A z$ Ég kapui (2013). Az említett múvekben az egyes ember a világvégtelenben keresi a helyét - messze az anyagi határokon túl. A darabok spirituális tartalmát a lelki mélység és az egyetemes kulturális örökség adja. A Miseparafrázis azonban címe alapján nemcsak spirituális programot rejthet, hanem szakrálisat is. A jelen szövegben szakrálisnak tekintem azt a múvészeti kompozíciót, amely a keresztény értékrend szerint a szentségre utal.

Terényi Ede - érthető okokból - az 1989 elôtti időszakban csak rejtett módon vállalhatta a nyílt szakralitást, így a mikor misét írt - akkor azt nem misének jegyezte le. Így lesz érvényes rá a mottónak választott és módosított József Attila-gondolat: „amikor misét ír az ember, akkor nem misét írni volna jō". A rejtjeles, nem misék azonban a gondolkodó alkotót új múfaji megoldásokra csábították, így mire misét írhatott, már létrehozta sajátos, szakrális, nemmise-írásmódját. A korai korszakból megemlíthetô az 1956-os forradalmat gyászoló Csángó sirató vegyeskar és a B.A.C.H. mise (1967) címú orgonamü. ${ }^{5}$ Terényi mújegyzéke szerint 1988-tól kezdve szaporodtak meg a vallási témájú (orgona- vagy orgonás) darabok, pl. Introitus (1988), Septem dolores (1988) vagy Stella aurorae (1988), illetve Octofelicitatis (1989) és Vier biblische Lieder - Münchener Codex (1989). ${ }^{6}$ A temesvári forradalmat követő rendszerváltás felszabadította az erdélyi alkotókat is, Terényi is megújulva alkothatta meg szakrális műveit. ${ }^{7}$ 1990-ben végre számos szakrális kompozíció robbant ki belőle, példaként említve a Die sieben Worte des Erlösers am Kreuz - orgonadarabot, a Hymnus pro Dominica Palmarum kórusművet vagy az ars poeticának is tekinthetô Csíksomlyói Stabat matert. ${ }^{8}$ A szakrális múvek még hét éven keresztül sorjáztak ujjai alól, így a Missa in A (1991/93), a Maria Madre (1992), a Mise egynemú karra (1993), az Il cantico del

5 Jellemző a korszakra, hogy nemcsak az Istent, de az ördögöt sem lehetett megvallani, így Vermesy Péter hiába küzdött hosszú ideig az Ördögráltozás Csíkban című operája bemutatásáért.

6 Egy múfaj megjelenése nem csupán életrajzi vagy kortörténeti okra vezethető vissza, hanem sok más szempontra is. Terényi szakrális kompozíciói is sokat köszönhetnek annak, hogy 1988-tól orgonára kezdett fogalmazni. A. M. Hotoran kutató élesen rávilágít, hogy az 1987 és 1997 közötti nagyszámú szakrális darab mind orgonaihletésű - feltételezhetően a jelen Miseparafrázis is. Anamaria Mădălina Hotoran: The Variational Concept in Eduard Terényi’s Organ Music, Editura Grafycolor, Cluj, 2019, 15.

7 Hausmann KóRódy Alice: Az erdélyi harmincasok. In: Adalékok a romániai magyar zeneszerzés történetéhez, (szerk.) Hausmann Kóródy Alice, Presa Universitară Clujeană, ClujNapoca, 2018, 32.

8 Terényi Ede: Alleluja. In: uő: Zene Tegnap, Ma, Holnap, Stúdium Kiadó, Cluj/Kvár, 2004, 214. 
Sole (1994), végül az Epiphania Domini (1997) és a Veni, veni Jesu (1997). A címek is jelzik, hogy egyedi felkérések, konkrét megkeresések és alkalmi kompozíciók éppen úgy születtek, mint az életmú érdemi irányát folytatók (pl. Stabat mater).

A szakrális vonalhoz ki nem mondva, de rendszerint hozzáértjük, hogy énekelt szövege legyen, amely a hitvallás drámáját megjeleníti. Az igazán nagy alkotók azonban a szavakat pótolni tudják múvészi jelképrendszerrel. A Miseparafrázis maga is tartalmazza e jelképrendszert, ahogy Terényi más múvei is. A szimfóniái közül négy cím utal szakrális programra. A Tér és fény szimfónia (Mise Erdély harangjaiért, 1988) az erdélyi falurombolás idején sírt fel, és kongatta meg a harangokat konkrétan az elveszett harangokért. Tragikus üzenetú, hogy e szimfóniát a mai napig nem mutatták be. Az 1998-as ikerszimfónia első fele, a Cantus hungaricus szintén hordoz belső programot: $A$ zöld erdôk liturgiáját. Noha nincs liturgikus elem az ikerszimfónia másik felében (Erdélyi kódex), annak zenéjében mégis találunk szakrális mozzanatot. Végül, az 1956-os áldozatok, forradalmárok és hősök előtt tiszteleg a Requiem 1956ért (Szimfónia orgonára és zenekarra, 2000). A Miseparafrázis szerkezetében a Tér és fény szimfóniához áll a legközelebb, amelynek tételcímei egybeesést mutatnak: I. Lento a la Pavone (Kyrie eleison), II. Allegretto grazioso (Gloria in excelsis DEO), III. Grave (Credo), IV. Presto feroce (Sanctus) ésV. Introduzione (Agnus DEI). A szimfonikus dramaturgia a Tér és fényben erősebbnek túnik a liturgikusnál, ahogy azt a fentebb elemzett mú esetében is láttuk. Szintén hasonló szerkesztési elv, ahogy az első és utolsó tétel egymásra rímel, illetve, hogy a Benedictus ez esetben is hiányzik. A szakralitásra történő utalás már a tételcímekben is látható, hogy nyomtatott nagy betű jelöli az Istent minden esetben - igaz, ebben a szimfóniában nincs elidegenítés, sőt hagyományos zenei attribútumokat hallhatunk a Gloriában és a Sanctusban is.

A múfajbesoroláshoz fogódzót ad az, hogy a Kamaraszimfóniák kötetben jelent meg. Ezáltal az In memoriam Bakfark (1978), Tinódi világa (1984), A héttornyú vár (1993), illetve az említett ikerszimfónia: a Cantus Hungaricus (1998) és az Erdélyi kódex (1998) stiláris-szerkezeti közösségébe került. Azáltal, hogy nem a Szakrális zene (Musica Sacra, 2008), sem az Egyházi darabok (Church Music, 2009) kötetbe került, távolságot tart a hagyományos liturgikus olvasattól. Besorolása azt is hangsúlyozza, hogy nem - a szakrális szertartáshoz rendelt - alkalmi zenérôl van szó. A müfaj-azonosítást viheti előre az is, hogy a kamarazenekari múvek jelentős csoportját képezik az hommage-alkotások, és jelen esetben nehéz elvonatkoztatni attól, hogy Kájoni-hommage-ról beszéljünk. Még közelebbi megfejtést jelenthet a szerző időskorban összeállított és tanítványa, Emil Gherasim által újrahangszerelt Fekete-piros sorozata, amely az azonos címú Kányádi-vegyeskart helyezi a középpontba. A XVI. századi témákat aktualizáló ciklus darabjai: a már említett Bakfark-, Tinódi- és Tündérszép Ilona és Árgyélus szimfónia, a Fekete-piros kórusmủ és a Julianus barát útján címú szimfonikus látomás. Ennek lehetne a hatodik darabja. Valójában az, aminek a címe is mondja: miseparafrázis - azaz nem mise, csak olyan, mintha az lenne. 
A Kájoni-idézetek azonban még egyszer gáncsolják a hermeneutikai értelmezést. Ezúttal nem térhetünk ki azokra a jelentős részletkérdésekre, hogy a kalandos életư Kájoni-kötet pontosan citált dallamait egykoron kik írták, milyen célból, milyen liturgikus és zenei közegben, s mely funkcióval bírtak. ${ }^{9}$ A Miseparafrázis hallgatói, hacsak arra külön bevezető beszélgetés fel nem hívja a figyelmet, nem fogják érzékelni sem Solymosi, sem Kájoni közvetlen szerzőségét, pusztán az idézetet és jó esetben annak stiláris idegenségét hallják. A tragikus hangulat és az eltérő zenei nyelvezet jól elkülöníthető, a többi azonban nem, mert nemcsak a kora barokk miseénekek, de a szakrális muzsika hagyománya Kolozsvárott, Erdélyben, de egész Közép-Európában is többszörösen megszakadt. A megszakítottság drámája a Miseparafrázis - címében is vállalt - talán legerőteljesebb programja. Nem véletlen tehát, hogy a megszakított hagyományt célkeresztbe állító mú múfaja oly sokveretư, s közben mégsem konkretizálható (legfeljebb nem miseként). Így kapott tehát Terényi posztmodern metafizikai látomása a szakrális erdélyi örökségről XVI-XVII. századi külcsínt és kortárs vonószenekari belbecset a Farkas utcai templom terében.

\section{A FIÚ DRÁMÁJA - TEOLÓGIAI OLVASAT}

Cesare Ripa az Ikonológiajját lapozva valószínúleg gyorsan megfejtené a zenei jelképeket. Ahogy azonban fennebb már kiderült, nem világosan körülhatárolható, egyes attribútumokat kell elhelyeznünk stilárisan jól megragadható értelmezési mezőben, hanem egymásra torlódó, megszakadt és aktualizált hagyományrétegek között kell időbe vetett értelmezési kísérletet tennünk. A szerkezeti elemzés során annyi nyilvánvalóvá vált, hogy a Kyrie bűnbánati könyörgése meghatározza a mú dramaturgiáját és programját. Az is tisztán kitünik, hogy a kisterc-osztinátónak, illetve az A-tonális centrumnak legalább zenei szempontból szerepe van. Amíg a bünbánati könyörgés az adott múvön túlmutat, addig az 1993-as zenei környezetben adott tonális centrum és hangköz nem. Igaz ez akkor is, ha az A-centrum egyébként nem akadémikus módon van jelen a múben, hanem a hangfüzérek mikro-polifonitásából bukkan fel a súlyos záróakkordokban. A jelentéssíkot kutatva immáron a liturgikus tartalmat szakrális programként olvasva kiderül, hogy mindegyik konkrét esetben a Fiúisten szekvenciájánál történt elöre nem látható zenei elkülönülés. A Kyriẻben tritonusszá válik a magasságban bemutatott kisterc(-áldozat); a Credóban a Ô szekvenciájánál lágyul el a zene, ám hamarosan megakad, s makacs kisszekundos ismétlésbe fullad, végül diadalmas tusba kezd (ti. „meghalt, eltemették, és harmadnapra feltámadott"). Az Agnus Deiben a Fiúistenhez, azaz az Isten bárányához szóló fohász

9 BENKő András: Kájoni János, a humanista muzsikus. Korunk 1981/11., 819-823. 
leveti a dallami keretet, és a végtelenbe kiált fel. A két dicsőítő tételben viszont a szentség megvallása idején válik motorikussá a zene. Jézust, az Istenfiút Terényi halandó emberként állítja elénk? A földi lét szükséges állomása a halál, amelynek árnya oly erősen érződik a teljes mise megrendült hangvételében, még a hagyományosan derűs Gloriában és Sanctusban is. Az Agnus Dei idézete pedig Kájoni Dies iraeszekvenciája, amely így végül rekviemmé avatja a misét. A Farkas utcai mise tehát a Fiústen gyászmiséje, ahol a kisterc a bécsi klasszikus siratómotívumnak feleltethető meg, az A-dúr pedig a világos, tiszta, égi hangnemnek. A zene konstruáltsága és természetessége, megrendült hangvétele és éles felkiáltásai, elidegenítő keretmotívumai arra utalnak, hogy személyes élmény (is) áll a mise programja mögött. Kájonival Erdély népeiért, a Farkas utcában a kolozsváriakért, nem miséjével a Fiúért sírva könyörgő szerző így állított emléket égi-közösségi és személyes pátriájáért. A jó hírt a szerző az utolsó ütemre tartogatta: a legmagasabb hegedúhang cisszé válva a zárlatot klasszikus A-dúrrá teszi, miáltal Terényi hitet tesz amellett, hogy van megváltás.

\section{ITA MISSA EST}

A kutató megírja szofisztikáltan tudálékos tanulmányát, és jó esetben a tiszta, világos alapelvek mentén a jól megragadható elemekből következetes levezetéssel érdemi olvasatig jut el. Minden értelmezés mögött azonban ott lappang a kérdés, hogy a zeneszerző vajon hitelesíti-e azt. Recepcióesztétikai jólneveltségünk természetesen hermeneutikai pajzsként véd a "gondolta a fene”-jellegű beszólásoktól, meg a szerzők önkényes, „még azt is el kellett volna mondani”-követeléseitől. És mégis, a múzsa, a fura, kis daimón, azt kérdezi, hogy a müre való rálátásunk belátással párosul-e, vagy a tủnő káprázat után az éji vak, önmagukban zárt homállyal. Ezért nemcsak misét írva nem misét írni volna jó, hanem értelmezést írva nem értelmezést írni volna jó.

\section{EDUARD TERÉNYI'S MASS-PARAPHRASES.TUNES FROM THE OLD AND THE CONTEMPORARY CHURCH ON FARKAS STREET}

\section{Keywords: Ede Terényi, missa brevis, tradition interrupted, sacral program}

Eduard Terényi, who has lived since his university years in Cluj, composed his Paraphrase Mass of Transylvania of the seventeenth century inspired by the protestant church on the Farkas/ Kogălniceanu street. The artwork crosses three aesthetic borders, similar to other Terényicompositions. First of all, he presents a Catholic mass in a protestant sphere. Breaking the long tradition of the human voice and organ employed in sacral works, Terényi uses strings and only imitates the choir. Finally, in his modern confession he evokes tunes from the $17^{\text {th }}$ century. In the vernacular language of the mass we can detect the organic reception of Béla 
Bartók and the similarity of Leoš Janáček', Steve Reich' and Gia Kancheli's style. In the mass he declares his faith in the communal ethos in the way of using the Latin and Hungarian sacred songs described by the Romanian monk, Ioan Căianu. Thus, the place (the church on Farkas street), the tradition (musica sacra in Transylvania) and artistic credo become ecumenical, universal and Cluj-like.

\section{MISA PARAFRAZĂ A LUI EDUARD TERÉNYI. MELODII DIN BISERICA VECHE ȘI CEA NOUĂ DE PE STRADA KOGĂLNICEANU DIN CLUJ}

\section{Cuvinte-cheie: Eduard Terényi, missa brevis, tradiția întreruptă, program sacru}

Compozitor clujean, Eduard Terényi a compus lucrarea intitulată Misa parafrază din Transilvania, sec. XVII. inspirată de Biserica Reformată de pe strada Kogălniceanu, Cluj-Napoca. Similar altor compoziții a lui Terényi, piesa trece mai multe granițe estetice. Intâi, artistul concepe o misă catolică într-un lăcaș de cult protestant. Întrerupe lunga tradiție a vocii umane și al orgii în muzica eclesiastică, Terényi folosește instrumente cu coarde și doar imită corul. În al treilea rând, evocă melodii din secolul al X́VII-lea. În limbajul autohton a misei putem detecta receptarea artei bartókiene și anume similarități cu stilul lui Leoš Janáček, Steve Reich și Gia Kancheli. Compozitorul clujean alege să-și declare credința prin versuri în latină și maghiară, notate demult de călugărul Ioan Căianu. Astfel locul (biserica reformată de pe strada Kogălniceanu), tradiția muzicii sacre din Transilvania și credo-ul artistului devin ecumenice, universale și clujene. 